\title{
The Markala Cooperative: A new approach to traditional economic roles
}

Susan Daughman

Mariam N'Diaye Thiam

Follow this and additional works at: https://knowledgecommons.popcouncil.org/departments_sbsr-pgy How does access to this work benefit you? Let us know!

\section{Recommended Citation}

Daughman, Susan and Mariam N'Diaye Thiam. 1982. "The Markala Cooperative: A new approach to traditional economic roles," SEEDS no. 5. New York: Population Council. 


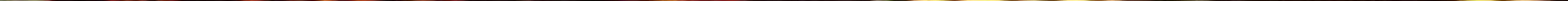


SEEDS is a pamphlet series developed to meet requests from all over the world for information about innovative and practical program ideas developed by and for low income women. The pamphlets are designed as a means to share information and spark new projects based on the positive experiences of women who are working to help themselves and other women improve their economic status. The projects described in this and other issues of SEEDS have been selected because they provide women with a cash income, involve women in decision-making as well as earning, are based on sound economic criteria, and are working successfully to overcome obstacles commonly encountered. The reports are not meant to be prescriptive, since every development effort will face somewhat different problems and resources. Rather, they have been written to describe the history of an idea and its implementation in the hope that the lessons learned can be useful in a variety of settings. They are also being written to bring to the attention of those in decision-making positions the fact that income-generating projects for and by women are viable and have important roles to play in development.

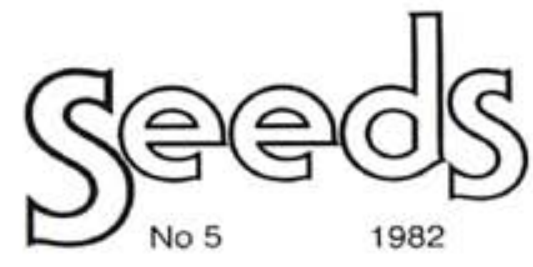

Publication of SEEDS is made possible by the support of the Carnegie Corporation, the Ford Foundation, Oxfam-America. the Population Council and the Rocketeller Foundation

Statements made and views expressed in this publication are solely the responsibility of the author and not of any organization providing support tor SEEDS 


\title{
The Markala Cooperative: A New Approach to Traditional Economic Roles
}

\author{
Story by Susan Caughman \\ and Mariam N'diaye Thiam
}

\section{Introduction}

The Markala Cooperative resulted from the resolution of a group of poor women in rural Mali to seek paid employment. When the twenty original members joined together in 1975, their goals were to earn a regular salary and to learn marketable skills. By 1981, these goals had been achieved. The women have established a successful cooperative business based on the production and sale of dyed cloth and laundry soap. In learning the necessary skills, they sought out job training unavailable to most women in rural Mali. Although they were helped by capital grants from several voluntary agencies, the members financed their own lengthy training through earnings. The experience of the Markala women has already inspired other cooperative businesses in rural Mall. It has also demonstrated that creating off-farm employment opportunities for women is a vital element of rural development projects. 
The town of Markala, population 8,000, is located on the Niger River, about 300 kilometers from the Malian capital, Bamako. Mud houses arranged around central courtyards make up the town's two residential neighborhoods. Once a rural, agricultural settlement like most throughout the country, Markala underwent a significant change when a dam and network of canals and dikes were constructed around the town to provide irrigation for large-scale agricultural endeavors which would produce cash crops such as rice, cotton and sugarcane. The construction and maintenance of the irrigation system brought thousands of laborers, semi-skilled workers, tenant farmers, and supervisory personnel to the area from all over Mali and from neighboring countries as well. Most of the men of Markala now work as wage laborers and not as farmers. Similarly, the traditional work of women has undergone a significant change.

Malian society places a high value on women's financial independence and
Malian women always have played an important role in support of the family. There is a clear division of responsibilities for men and women. For example, men are expected to provide housing, wood and the staple grain such as rice or millet. Women provide their families with clothes and the ingredients that make up "the sauce", the stew of meat or fish, vegetables and spices that is combined with rice or millet to make up the traditional Malian meal. On the farm, women wove cloth from cotton grown in their husbands' fields and grew vegetables for "the sauce" in their own garden plots. Today, in towns like Markala, not only the men, but the women too must earn money in order to buy both clothing and food. However, unlike the men, they have not benefited from the training programs and employment opportunities opened up by the irrigation project.

To make matters worse, 1968 to 1973 was a period of severe drought in the Sahel region of West Africa. Although it did not bring starvation to Markala, it did cause

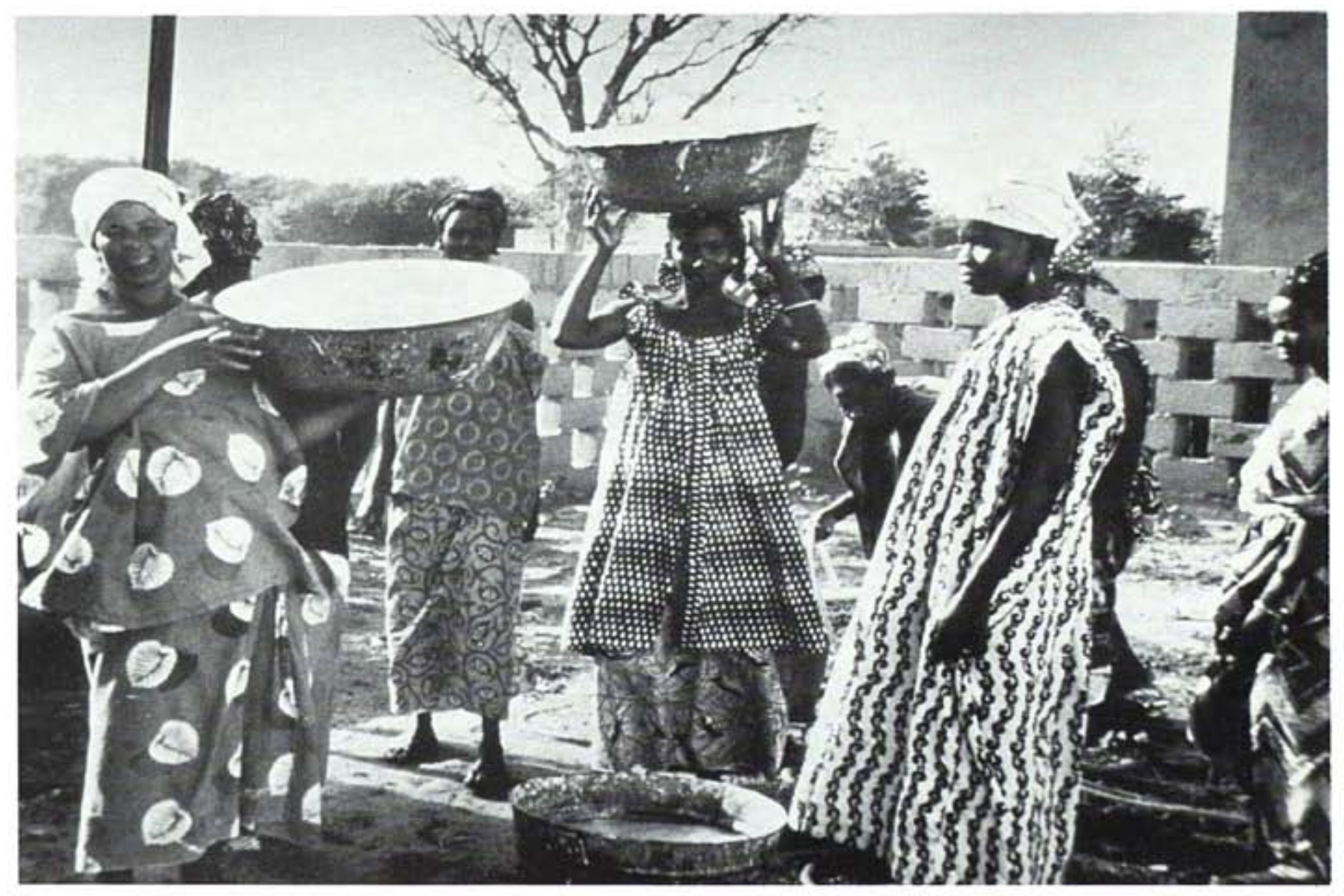




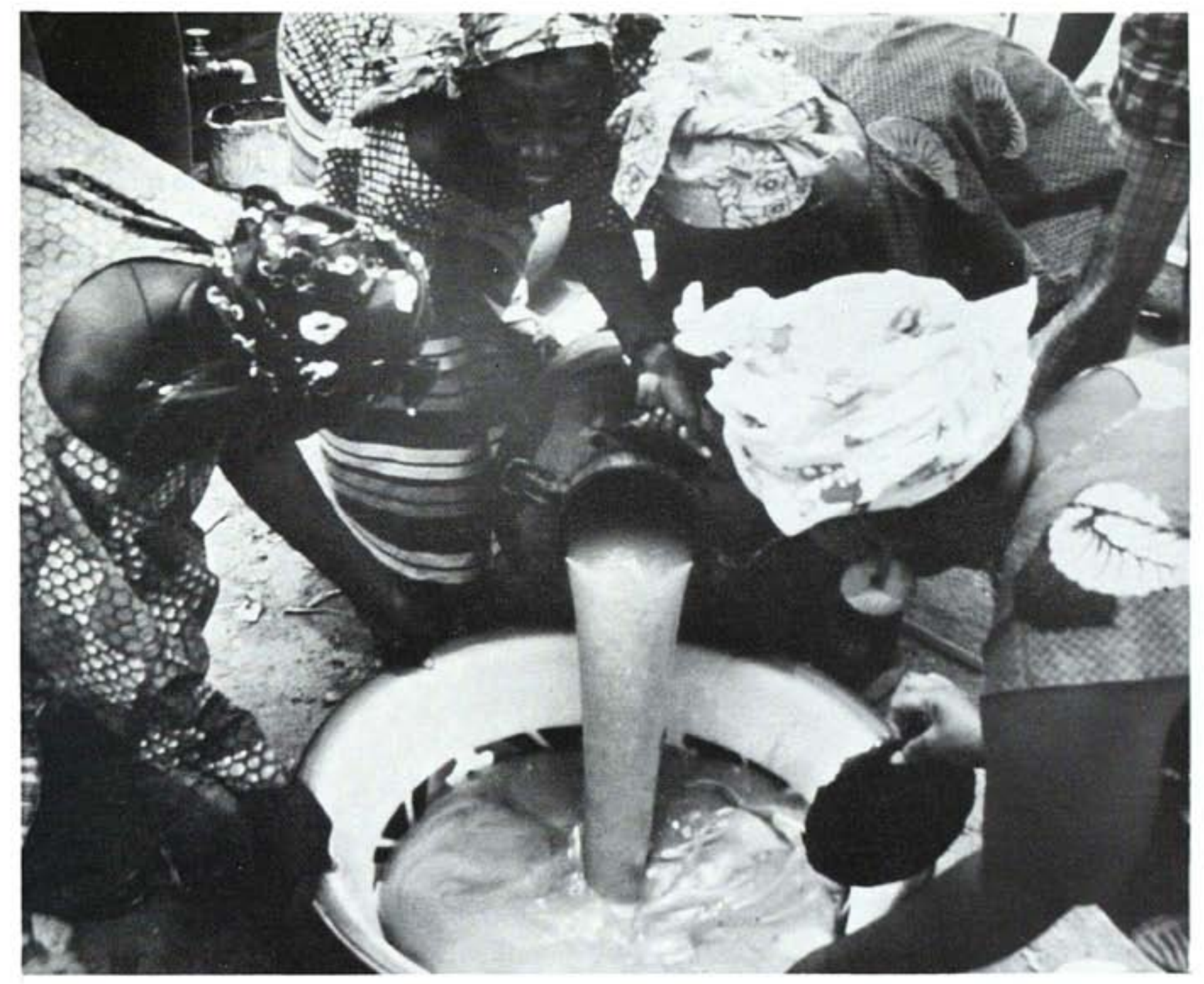

great hardship. Staple foods became difficult to obtain and rose dramatically in price. The cost of millet, for example, escalated $800 \%$ between 1973 and 1975 !

In order to earn money, Markala women engage in a variety of incomegenerating activities such as small-scale trading and food processing. These ventures, never very profitable, became totally inadequate in the inflationary economy that followed the drought. So in 1975, at the suggestion of a local official of the Ministry of Agriculture then residing in Markala, a group of local women came together to discuss their problems and what might be done. They were determined to do something to improve their ecomomic situation and eliminate the insecurity of their lives. They decided to join together in a form of economic organization-a cooperative.

\section{Setting Up the Cooperative}

For the Markala women, the decision to join together in a cooperative was a daring step. Though collective work groups are common in Mali, joint ownership of resources is very unusual, especially with non-relatives. However the pressure to earn needed funds had become intense and the old ways no longer were proving to be adequate. So, putting any personal misgivings aside, the group decided to move ahead with plans for a cooperative.

A major incentive to undertake a cooperative business was the desire to learn new trades. Many economic activities in West Africa are the province of certain ethnic groups or families, the necessary training passed down from one generation to another. The women viewed the coopera- 

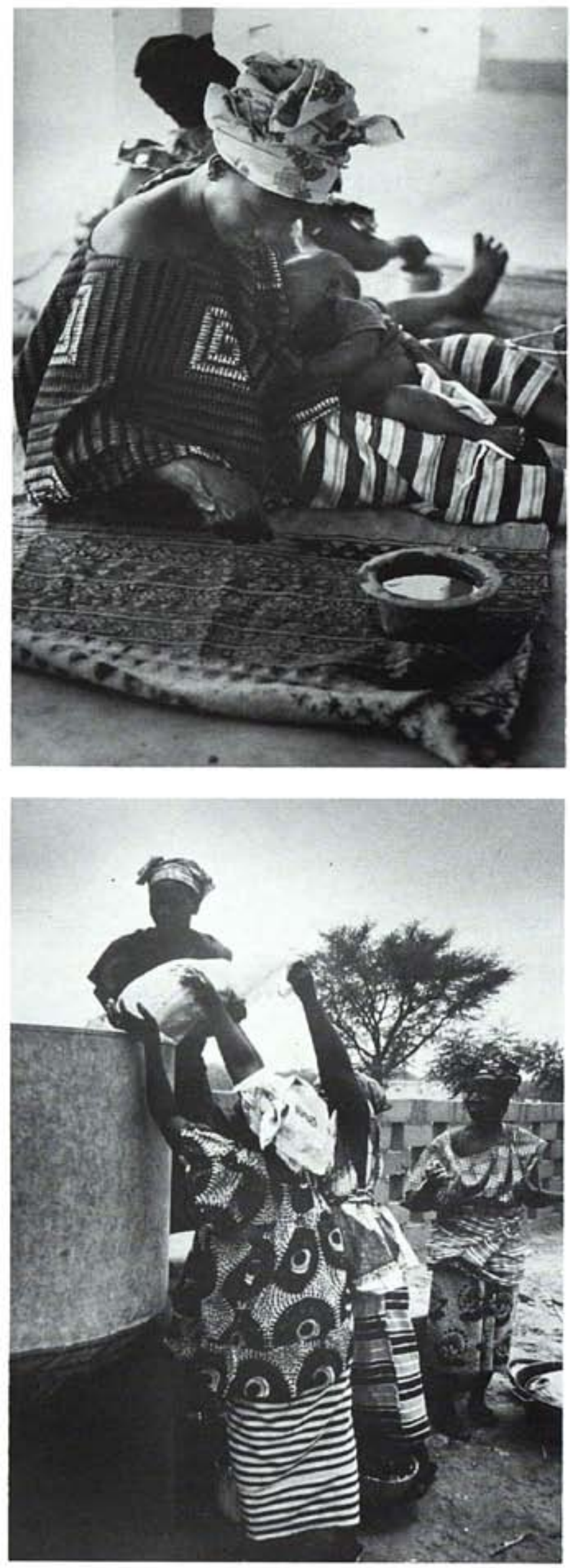

tive as an opportunity to receive new skills training just as the men had received training through the irrigation project.

In a series of meetings that took place over three months in 1975, the women discussed their problems and what they might do to earn money. Before beginning any business activity, they agreed on some ground rules:

- The group would be open to any woman in the town who wanted to participate.

- The membership fee would be low, so no one would be excluded because she had little money. (The initial fee of 1.000 Malian Francs (MF) or about U.S. $\$ 2.50$, was lowered to $100 \mathrm{MF}(25 \not)$ when it was discovered that many women otherwise could not afford to join.)

- The main purpose of the cooperative would be income-generation. From the onset members rejected activities such as literacy training and health education as irrelevant in light of their financial needs.

- All important decisions would be made by the group members. The women would not call on local political or government officials for leadership, as similar groups in Mali often did. Though they would be careful to discuss their project with local authorities, the members would retain responsibility for decision-making.

The women first considered the problems they hoped to solve and then decided what business activities might best meet their needs. As traders and food processors, their incomes were erratic; each day brought a new anxiety about feeding their families. Thus they needed not only a larger cash income but a steady one. Any seasonal activity, such as gardening or fishing, would not be suitable. They needed an activity with flexible hours, because child care and household chores took time each day. Members also wanted to increase their 
ability to find employment as individuals. not just as a group. They needed to learn skills that would permit them to earn a living wherever they might be.

In the end, cloth-dying and soapmaking seemed to best meet their requirements. These skills, they felt, would be valuable for each member whether or not the group enterprise succeeded. Several other considerations were important in their choice. The necessary raw materials were available locally and both cloth and soap were always in demand. Even more important, cloth-dyeing and soapmaking are traditionally female occupations in Mali. The women's unusual venture was already the subject of controversy in town, so they felt it was essential to choose activities considered by their community to be appropriate for women.

Approximately 200 women expressed an interest in joining the cooperative and most attended one or more of the planning meetings. However community skepticism and the prospect of a long training period dissuaded most of them from continuing with the cooperative. By the end of 1975 , twenty determined women began working in borrowed rooms in the back of a local school and the Markala cooperative was in business.

\section{Trial and Error}

To begin the cloth dying the cooperative, with the assistance of a Ministry of Agriculture official, received a $\$ 600$ grant from a United Nations project in Bamako that provided the initial capital necessary to purchase cloth, dyes and string, and to hire a well-known cloth dyer to come to Markala from the capital to train the members. The cloth-dyeing process proved to be complex and the women found it useful to divide themselves into two groups. One group concentrated on mastering the techniques of dyeing with clay, a traditional art of the Bombara, one of Mali's ethnic groups. A

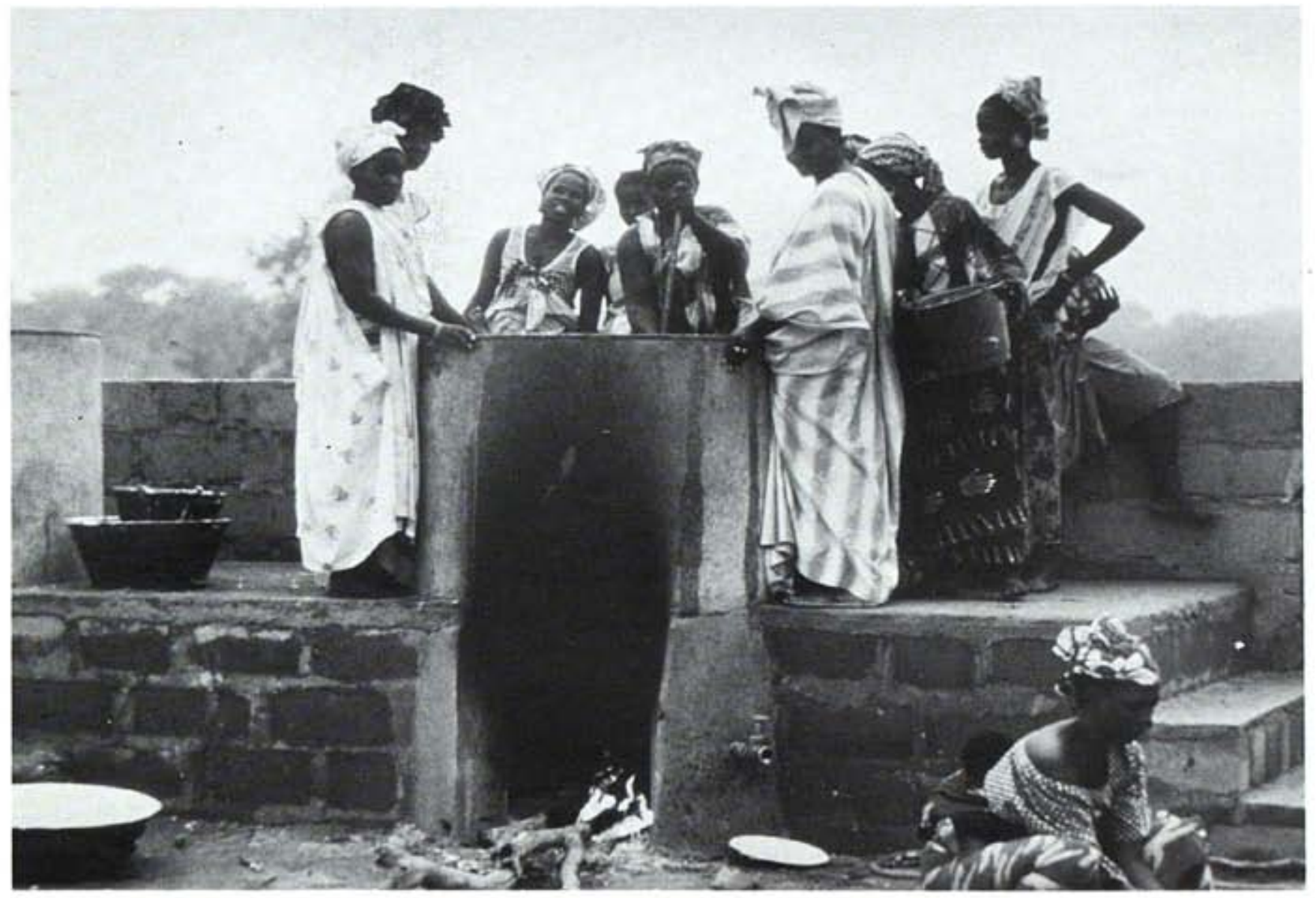


sure eye and a steady hand are required to paint accurate designs on hand-woven cloth using a small stick. Many months of practice were necessary before the women were producing saleable cloth. The other group chose to learn tie-dyeing. Patterns are tied, wrapped and sewn on to white cloth which is then dyed in a vegetable or chemical bath. When the threads are removed, a white pattern remains on the colored cloth. This technique proved even more difficult to master than the clay dyeing process.

The first two years of cloth production were marked by heavy losses which members chalked up to training costs. Still they remained determined to perfect their skills and in 1977 and 1979, members participated in advanced training programs held by the American Friend's Service Committee (AFSC) in the Gambia and Mali. By 1979 the women felt their products were equal to those of Mali's better known cloth-dyers.

It took an equally long time for the members to master the soapmaking techniques. The women first hired local soapmakers to teach them a process using fish oil. But they encountered difficulties: fish oil was not always available and, in any case, its strong odor made the soap saleable only when no other was available. Then the group experimented with shea butter, an oil made from the nut of a local tree, but they were unable to produce a soap that lathered well.

Then in 1979 the Ministry of Agriculture, with the collaboration of the American Friends Service Committee, began offering technical, financial and marketing assistance to women's producer groups in Mali under a program called FEDEV (for Women and Development in French). FEDEV hired a Ghanian soapmaker, Peter Donkor, to advise the group. He suggested combining two different oils to produce an odorless soap that lathered well. Donkor also introduced a new soapmaking process in which the oils, caustic soda, and water are boiled over a wood fire. Up to that time the group had made soap in what is called "cold process" soapmaking by stirring the ingredients together.

Boiling not only produced more soap with the same amount of oil, but it also got rid of the odor. The new boiling process was somewhat more difficult than the stirring technique because it required accurate measurement of raw materials and quick judgement about how much water to add. But thanks to their years of experimentation with oils and caustic soda, the women learned Donkor's new techniques rapidly. Within a week they were able to produce a high-quality laundry soap. Donkor returned in a few months to help the group install two soap-boiling tanks which gave them the capacity to produce several thousand bars of soap a week.

\section{Steps Forward}

By 1978, cooperative membership had grown to 50. Most of the members come from the lower income strata of Markala. The majority are married women over 30 years old; $64 \%$ of the marriages are polygamous with household duties shared between one to three co-wives. Only eight of the members have attended primary school and none completed their studies; two members speak some French, the national language. Yet by 1979, despite low incomes and continued criticism of townspeople who, seeing no financial gain accused the women of wasting their time, cooperative members had not only become technically proficient in two major skill areas but were well on their way to establishing their group as a viable business.

One important step was to register the group as a producer cooperative under Malian law. This procedure, which is necessary for recognition as a legal entity by the Government, was long and complicated. It is unlikely that this group of illiterate women would have been able to complete the required bureaucratic procedures without the assistance of FEDEV staff. 


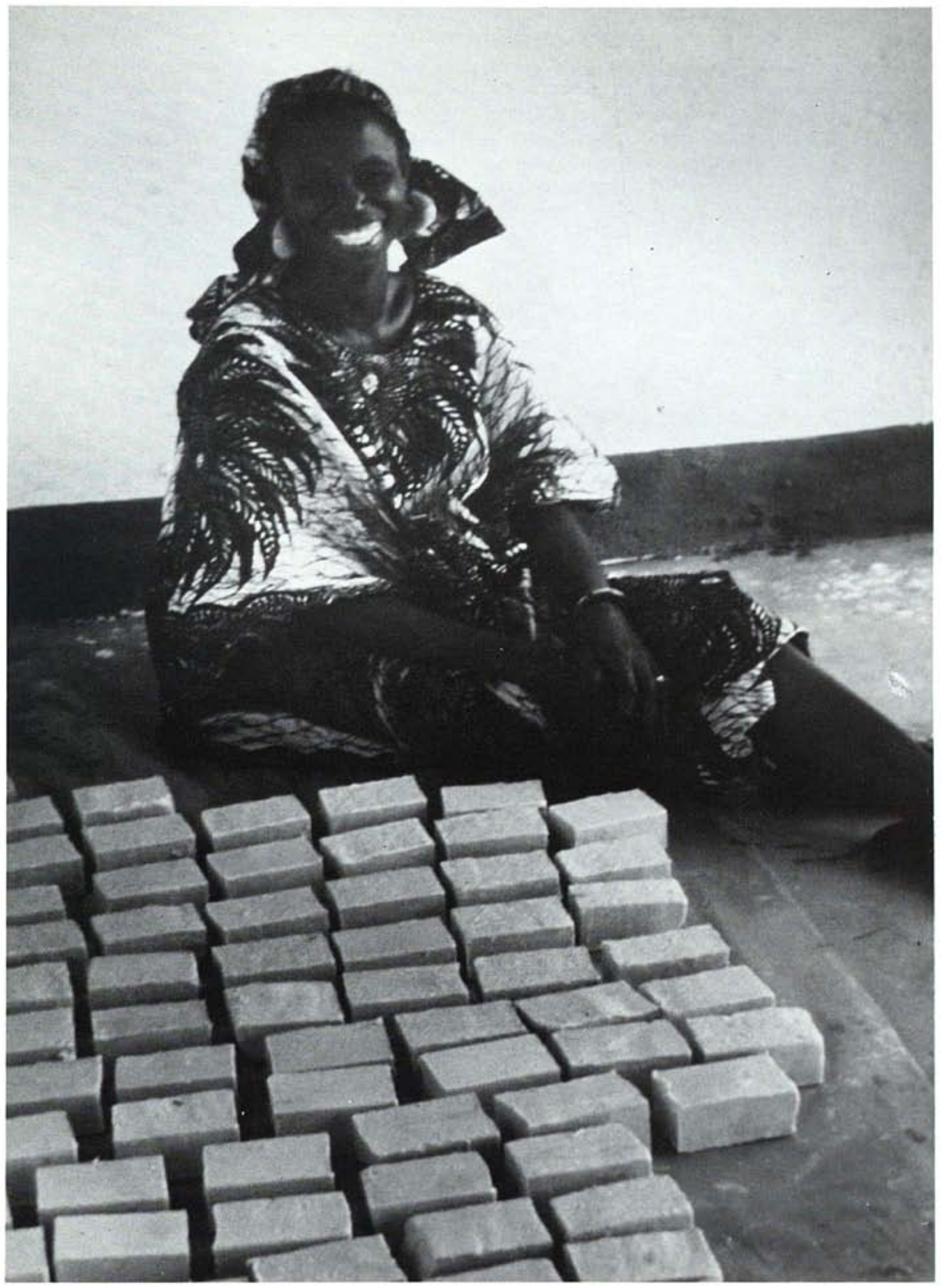


Another problem was solved when the group gained a permanent workshop, after several years of temporary locations and storage problems leading to a terrifying incident where a child tried to swallow caustic soda. With a grant from NOVIB, a Dutch voluntary agency, a cement building was completed in 1979; it consisted of a large room with shaded porches on either side so that workers could move outside during the hot months.

Along with the other visible evidence of the members newly acquired skills, _- dyed cloth and good-quality soap - the building brought about a change in the townspeople's attitude toward the group's venture. Skepticism changed to admiration, and over time the cooperative found itself with many requests for membership. Local officials, astounded that a group of illiterate women owned a major building, began to consider the cooperative as a genuine business venture rather than writing it off as a social club as they had in the past.

\section{Organization}

In addition to problems in acquiring technical skills, the members faced difficult decisions about how to manage their business. Since the women had no tradition of sharing resources, managing the cooperative's assets was a key area of potential difficulty. Committees were set up and the members elected officials and bookkeepers. The daily work schedule was set up to permit a certain amount of flexibility. according to members' duties at home. Women in polygamous marriages, for example, whose cooking duties were less frequent, were required to be present more often than members who had to cook each day.

Because one of the women's goals had been to assure themselves a minimum stable income, they decided to pay each member a regular monthly salary from cloth dyeing profits. This monthly salary began at 2000 Malian francs (\$5) in 1976 and had

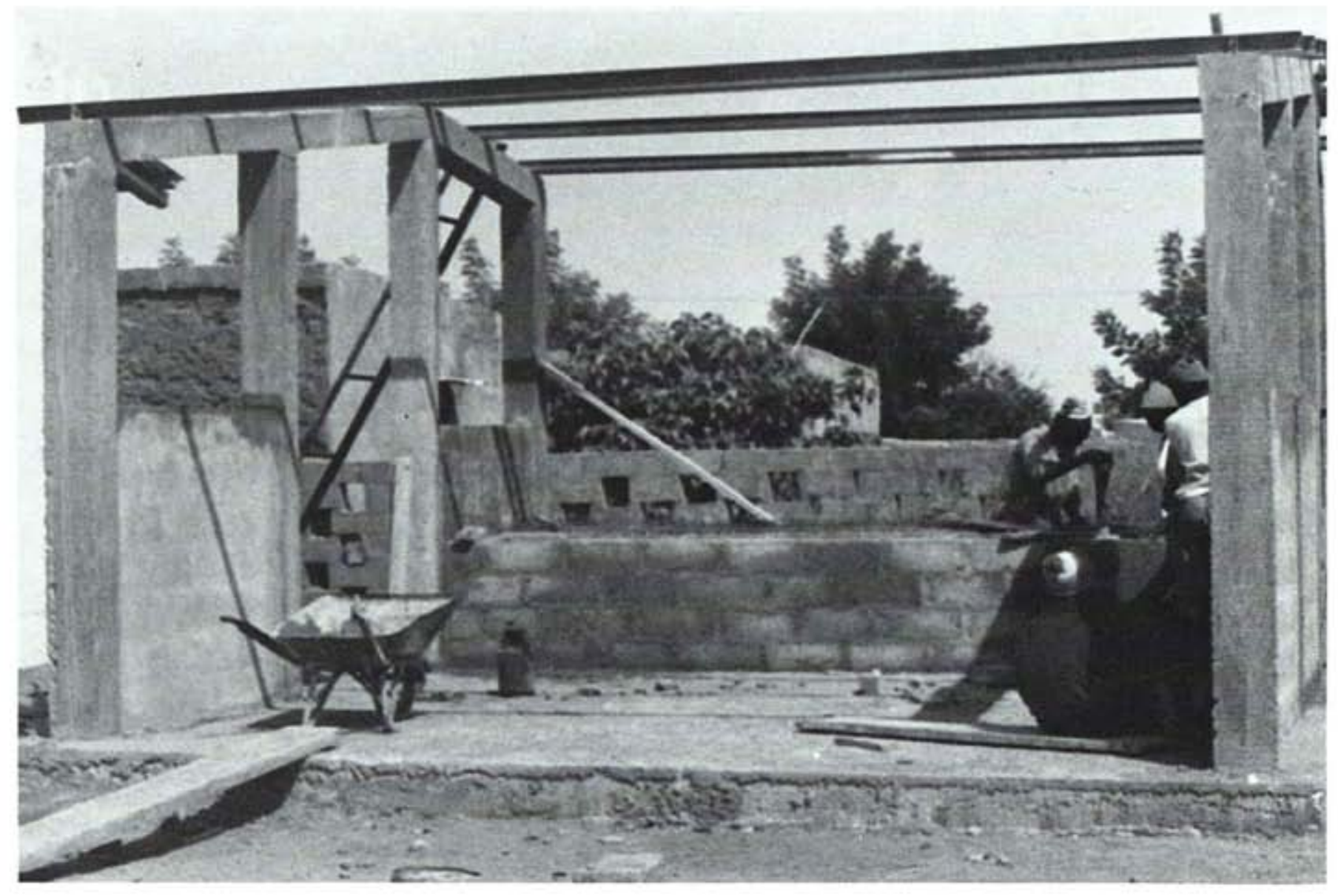




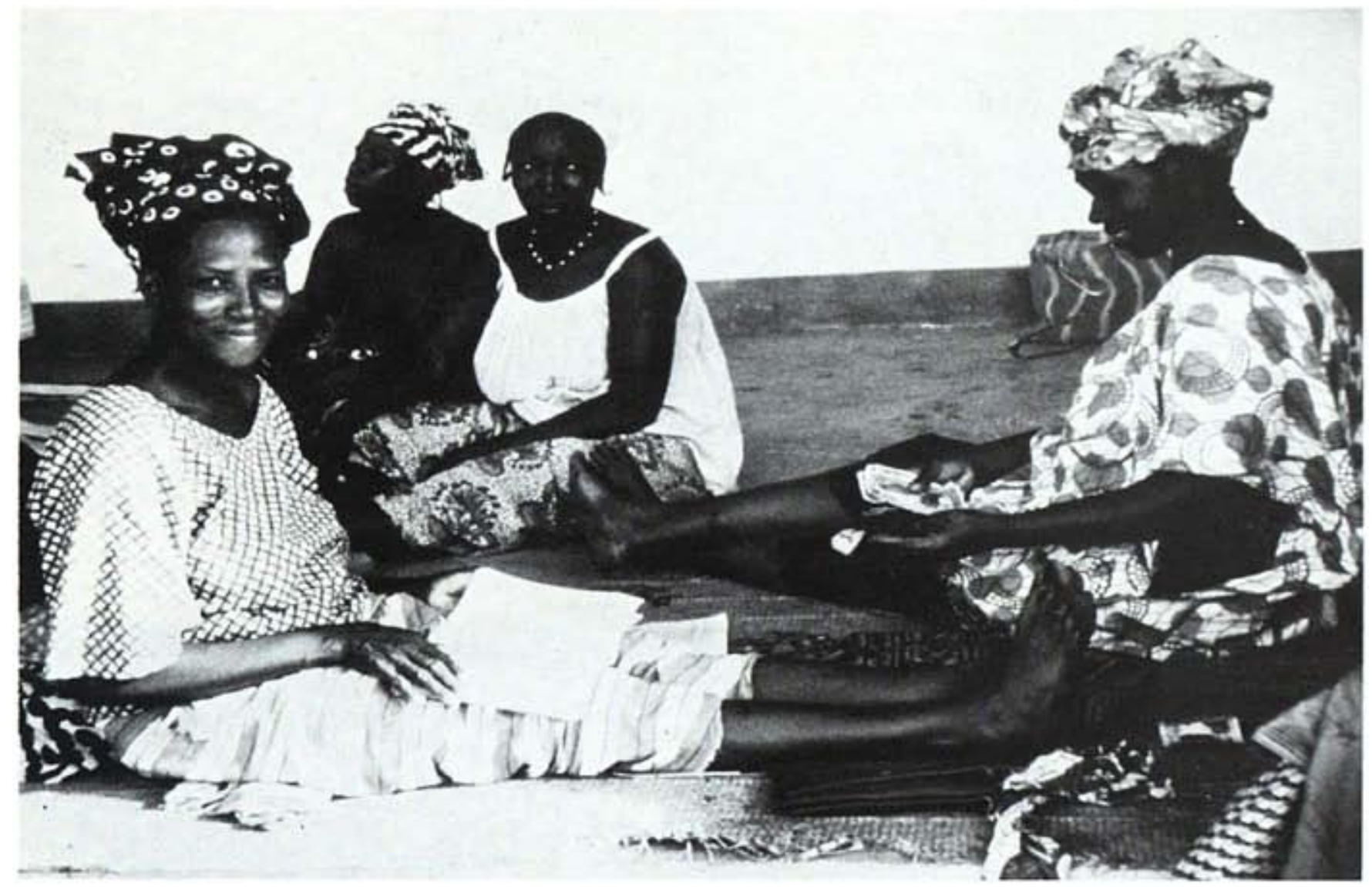

increased to $4000 \mathrm{MF}(\$ 10)$ by 1980 . Though small, it represented an important source of security for members.

Meeting the payroll each month remained the highest priority even when the cooperative had little income. Members often borrowed against expected profits or paid themselves with funds that might more profitably have been reinvested in raw materials. But despite the strain, members feel strongly today that without that regular salary they would have found it difficult to persist during the years of apprenticeship.

Facing another controvertial issue, it was decided that each member would be paid the same monthly salary regardless of how much each woman produced. In part this decision reflected the difficulty of measuring individual production levels. On soapmaking days, for example, everyone helps in measuring oils, weighing caustic soda, boiling the mixture, filling the molds, and later cutting the batch into small pieces. Similiarly, a piece of cloth might have been tied by one woman, dyed by two others working together and rinsed by a fourth; the threads might have been removed by a fifth. For this reason, the members decided to view profits as belonging to the entire group and to divide them equally.

On philosophical grounds, too, a majority of members felt that equal salaries were necessary to promote group unity and discourage jealousy and quarrels. Many of the women feel today that the group's survival is due to the equal payment system. But some cooperative members resented the inequity of a system that rewarded all members equally - even those who were less talented or hardworking.

In an attempt to respond to this criticism, the members devised a quota system. A small sum is subtracted from the monthly salary of any woman who does not meet minimum production and attendence quotas. In practice, however, this system has not resolved the tension between those who prefer to sacrifice some profit in order to keep the group alive and those who view the equal payment system as exploitation. 

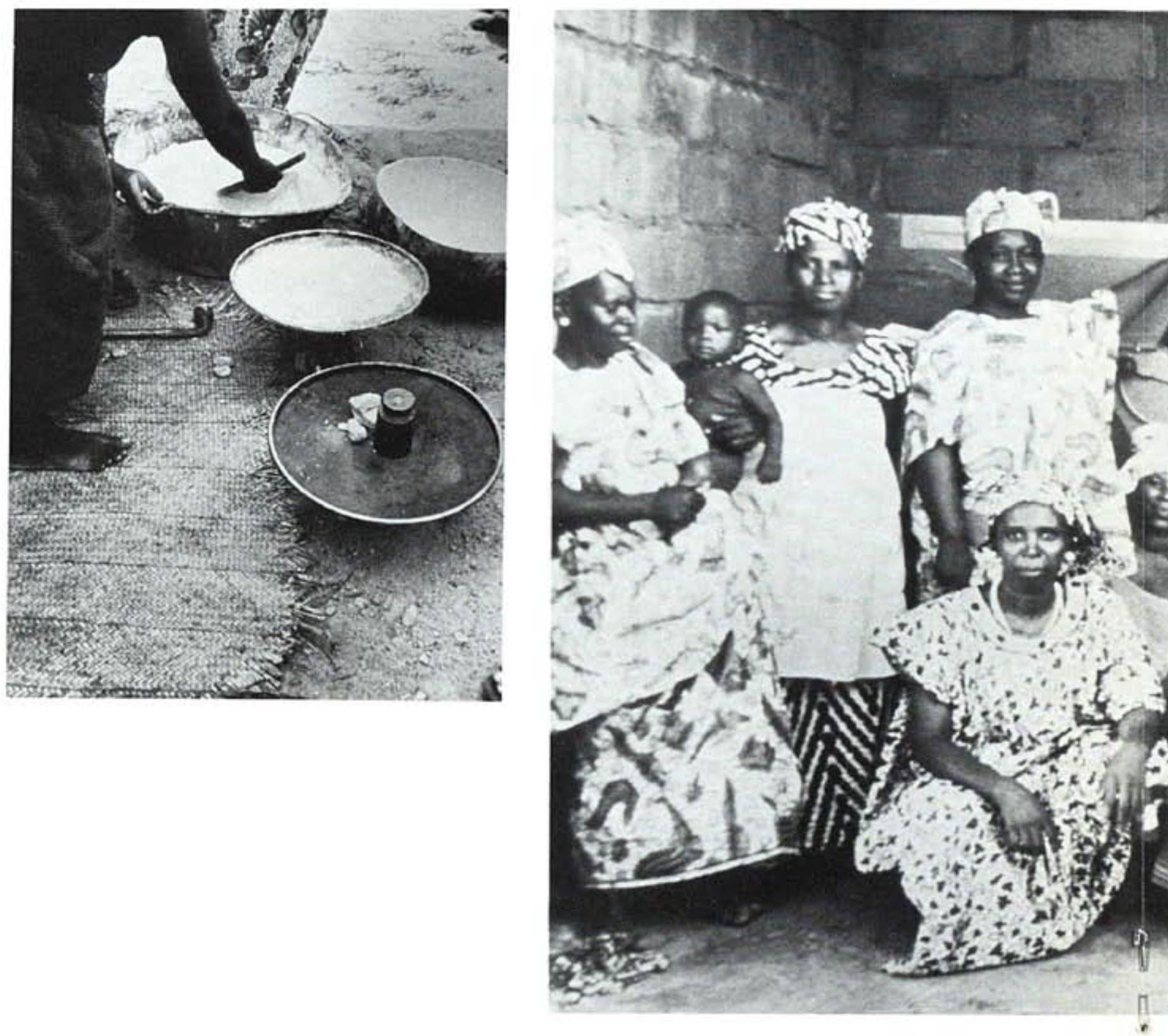

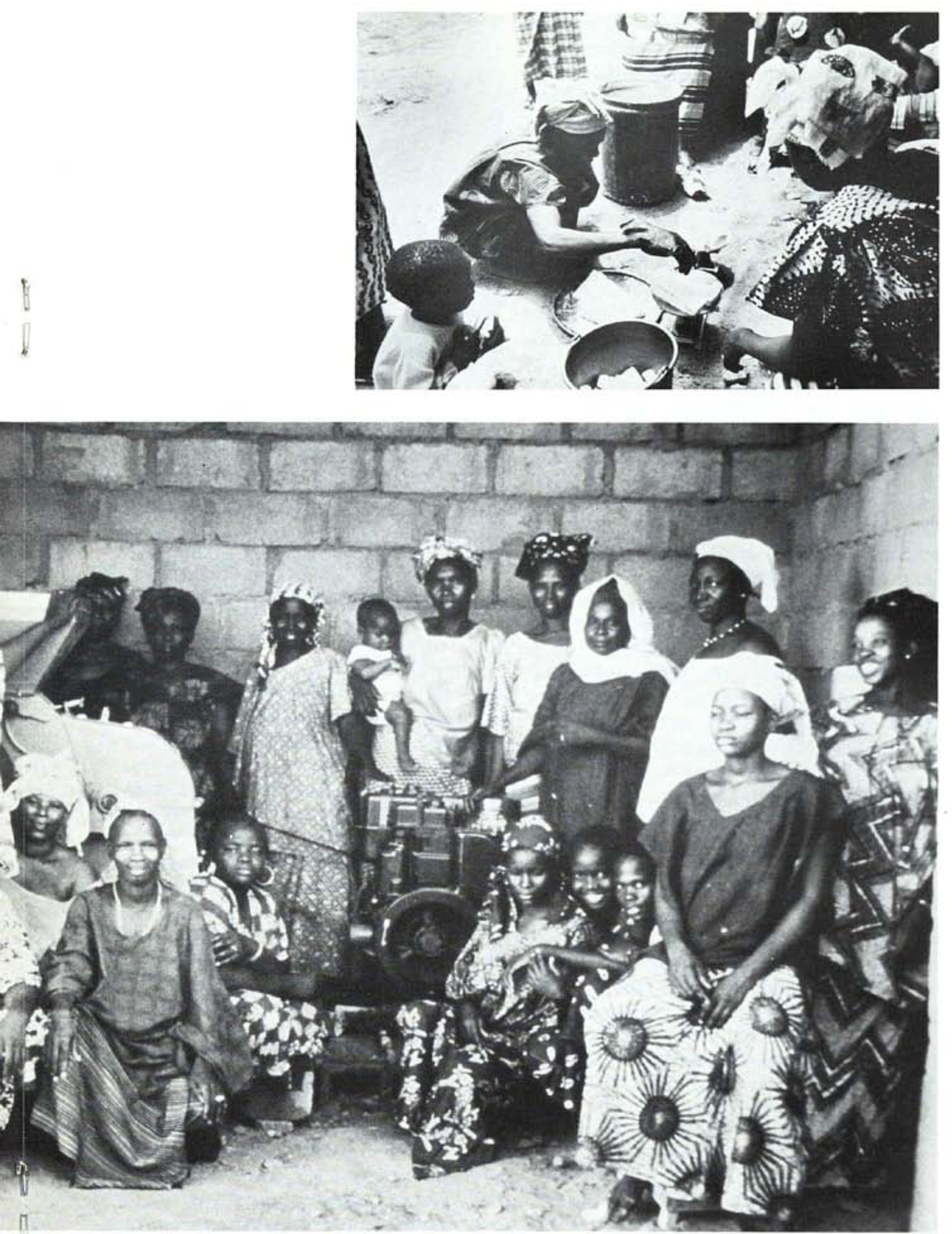
Difficult decisions like these were often made only after months of discussion. But through solving problems together, the group became loyal and cohesive. In the beginning, the women had joined in the hope of individual gain; but a commitment to the cooperative venture began to be important as well. When the cooperative had 50 members the group decided that the high cost of training new members required them to close the cooperative until their finances were more stable.

\section{Problems}

For the first few years, the cooperative's revenues came almost entirely from the sale of dyed cloth. As members became more skilled, their production gradually increased until it outstripped local demand. Although the cooperative's cloth is much admired by local women, few can afford to buy more than one piece a year. Thus the cooperative faced a marketing problem.

In 1976, a modest store, La Paysanne, opened in Bamako. Operated by FEDEV, it is designed to market the products of rural cooperatives. As it grew, it marketed an increasingly large percentage of the Markala Cooperative's cloth. By 1980 , almost all the cloth produced by the cooperative was sold on consignment in Bamako.

The store provides the cooperative with a reliable marketing outlet, access to a wide clientele, and a regular gross revenue averaging about 400,000 Malian francs (U.S. \$1000) a month. Participating in the store also has other benefits: it has forced cooperative members to improve the quality of their work and provides them with a source of raw materials at wholesale prices.

But marketing cloth through the Bamako store also presents a number of difficulties:

- First, transportation between Bamako and Markala is costly, making frequent trips by members to pick up raw materials and deliver finished cloth difficult.
- Second, information from the store about the colors and styles that appeal to clients is slow to filter back to the dyers. The cooperative therefore cannot adapt production rapidly to changes in demand.

- Third, since all cloth is sold on consignment, there is often a three-to-six month delay between the purchase of raw materials and the receipt of payment for dyed cloth. Lack of capital frequently forces the cooperative to borrow against future sales in order to buy more raw materials and continue production.

- Fourth, the cooperative depends almost entirely for its income on a retail outlet 300 kilometers away where management decisions are made with little input from cooperative members. Even though the Bamako store is a non-profit organization that exists only to market cloth produced in rural cooperatives, the Markala women have hesitated to involve themselves in its management. They regard it as an urban affair.

- Fifth, a high percentage of the store's clients are expatriates, an unreliable market on which to build a business.

For these reasons, as well as because of the low profit margins on dyed cloth, cooperative members are now attempting to find ways to diversify their sources of income. A millet-grinding mill seemed a good possibility since Malian women often pay to have their millet ground outside the home. However the cooperative's soapmaking business seems to hold the most promise of increased revenues, since its quality is appreciated in Mali and factory made soap is often in short supply. But so far, problems with inavailablity of raw materials, packaging and marketing have limited the group's income from this product.

Members sell soap directly to individual buyers at the cooperative. They are now seeking merchants to sell the soap 


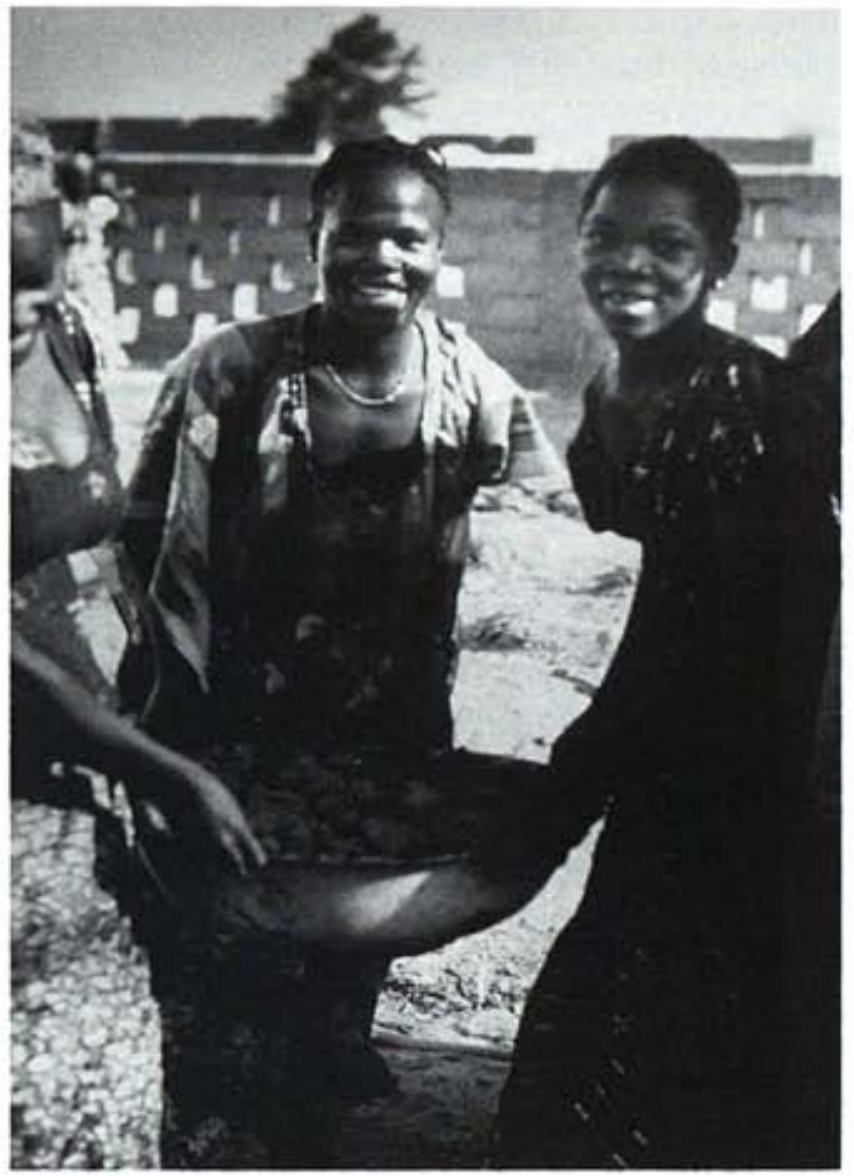

in other Malian towns, but transporting it in large quantities will require packaging the soap to prevent it from drying out, two problems the cooperative is currently addressing. In the future members hope the greater success of their soapmaking venture will permit them to rely less on a single product, dyed cloth, for their income.

Record-keeping has been another source of problems. The cooperative women preferred to call on the services of their own members rather than involve outsiders in their finances. As a result, the two literate cooperative members were chosen as bookkeepers. The bookkeepers devised their own record-keeping systems and kept careful track of all expenditures as well as attendance, production and soap inventories. As the cooperative's business has grown, adding new activities and involving more complex transactions, these systems have become less and less adequate. The members need reliable and timely information about the profitability of the cooperative's ventures in order to make decisions about purchasing raw materials or changing production schedules. Although the group has sought bookkeeping assistance from the local cooperatives agency, in the end they devised a unique and unorthodox system of their own. The group has assigned the responsiblity for the income from different ventures (one batch of soap or one month's sale of cloth for instance) to different illiterate members. In their view. this method balances the two literate members' control over written records and spreads responsibility for finances widely. While their system complicates attempts to gain an overview of the cooperative's finances, it is one that members value highly. The cooperative's members need innovative assistance to design a flexible accounting system that incorporates their own methods with traditional bookkeeping techniques, and helps them prepare profit and loss statements.

Lack of working capital has been an ongoing source of difficulty. Members must stretch the cooperative's resources each month simply to meet the payroll and buy raw materials for the next month's production. Thus, they are unable to stock raw materials when prices are low - an especially important consideration for soapmaking because shea butter, the staple oil, is harvested and processed in August and September each year and triples in price later in the year. Members would like to increase cloth production but they cannot afford to invest in cloth and dyes and then wait six months to receive the income from sales. Recently, however, the group received a working capital grant from OxfamAmerica to permit investment in raw materials and thus allow an increase in production.

The cooperative's decision to remain as independent as possible has meant that profits build slowly. The grants received by the cooperative (totalling some $\$ 75,000$ over seven years) cover only specific projects - the cooperative's building, for example - or short term training programs. The day to day costs of salaries, water bills, transportation and a host of other operating 


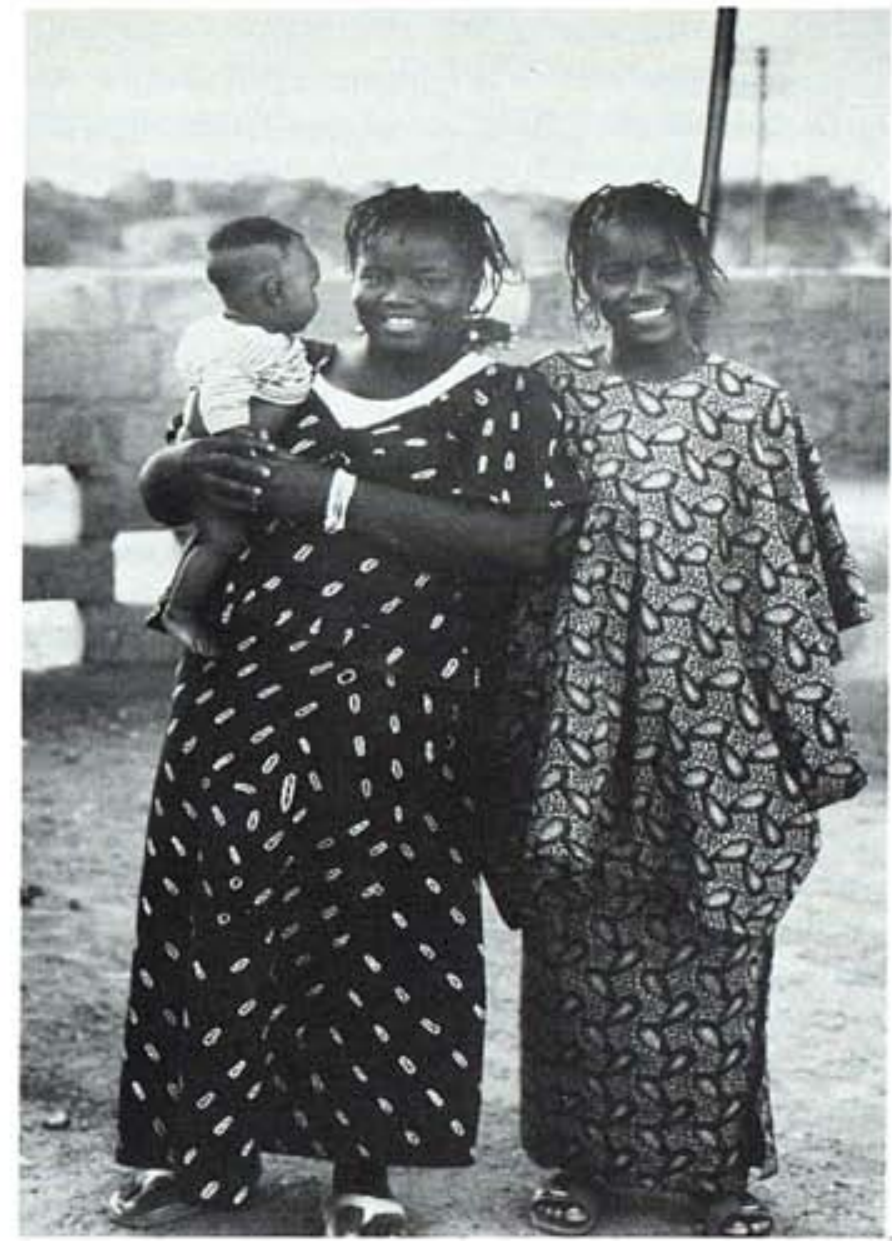

expenses which keep the cooperative functioning are supported from profits generated by cloth sales. The members themselves subsidized their own, lengthy job training process; an expensive effort that kept salaries low for many years.

The fact that their income from five years of work has been low has only strengthened the women's resolve to increase their earning power. As cooperative production expands, the members hope salaries can be increased.

Though the members are not yet satisfied with the financial return on their venture, their commitment to the cooperative is unswerving. They are expansive about the benefits gained. The Markala women see their occupations before they joined the cooperative as inconsequential: "I was doing nothing, so I joined the cooperative." It is a source of great pride to these women that they are now skillful cloth-dyers and soapmakers with a place of employment and a monthly salary. Their daily anxiety of the past has been replaced by a new security. Many of the members, confident of their own ability to earn money in the future, are teaching their skills to their daughters so that they too will be employable.

Because the cooperative salary meets only a small proportion of the women's monthly expenses, many earn additional income at night using the skills learned through the cooperative. "Before I had no trade," said one of the women, "Now I am able to meet my expenses. I can tie cloth or make soap at home at night."

The women value the support of their fellow cooperative members highly. "If I need something, if I have difficulties, I am helped by a cooperative member." They feel that working in a group has been highly beneficial. "Some people have better ideas than others so when you work together you learn."

The financial advantages of the group extend beyond the monthly salary. Cooperative members have formed a rotating savings club to which each contributes from her salary. Each month, in turn, two members receive 25,000 Malian francs (U.S., \$50). For most members, who are unable to save at all because of the cost of feeding their families, this club represents their only chance to assemble a significant sum of money. Most use the money to pay back loans or buy clothes for their children. But several have invested their savings one in a cart that she hires out, and another in a soft drink business. The cooperative also has a special fund to help members in emergencies, such as family illness.

These achievements have not gone unnoticed. In addition to gaining their neighbor's approval, the Markala women have attracted official attention. The FEDEV program, inspired largely by the example of the women in Markala, now assists some 20 groups in Mali. Many of them have sent members to Markala for training and women from other countries have visited Markala to learn about the cooperative's experiences. (See Appendix) 


\section{Lessons}

The persistance and initiative of the Markala Cooperative has demonstrated that poor nonliterate women can collaborate successfully on economic ventures. Perhaps most importantly, through their action and the organization of their cooperative business they have made an important statement about the role of women in rural Mali. Rural women who are responsible for feeding their families require job training and employment opportunities that will provide them with a steady income. Although increased agricultural production is an important goal of rural development projects, the cash needs of women, on and off the farm, must also be considered if family living standards are to be raised.

Those who wish to increase incomes among rural women can learn a number of useful lessons from the experience of the Markala cooperative:
1. The initial activity undertaken by a cooperative should promise a clear and immediate benefit to the participants. Experts would probably not have advised cloth-dyeing as a start-up activity for women in rural Mali. Profit margins are small, training is long and marketing, difficult. But the members believed cloth-dyeing would be useful to them whether or not the cooperative survived, and they were willing to commit themselves to mastering the necessary skills. Thus cloth-dyeing was ideal for the early years when the cooperative was fragile and group spirit was minimal. Now that the cooperative is stronger and more cohesive, members can move on to less conventional, more profitable activities.

\section{Women should choose the struc-} ture of their own organizations, even if their decisions appear illogical to outsiders. The Markala women organized their cooperative in ways that defy commonly accepted business practices. Regular sal-

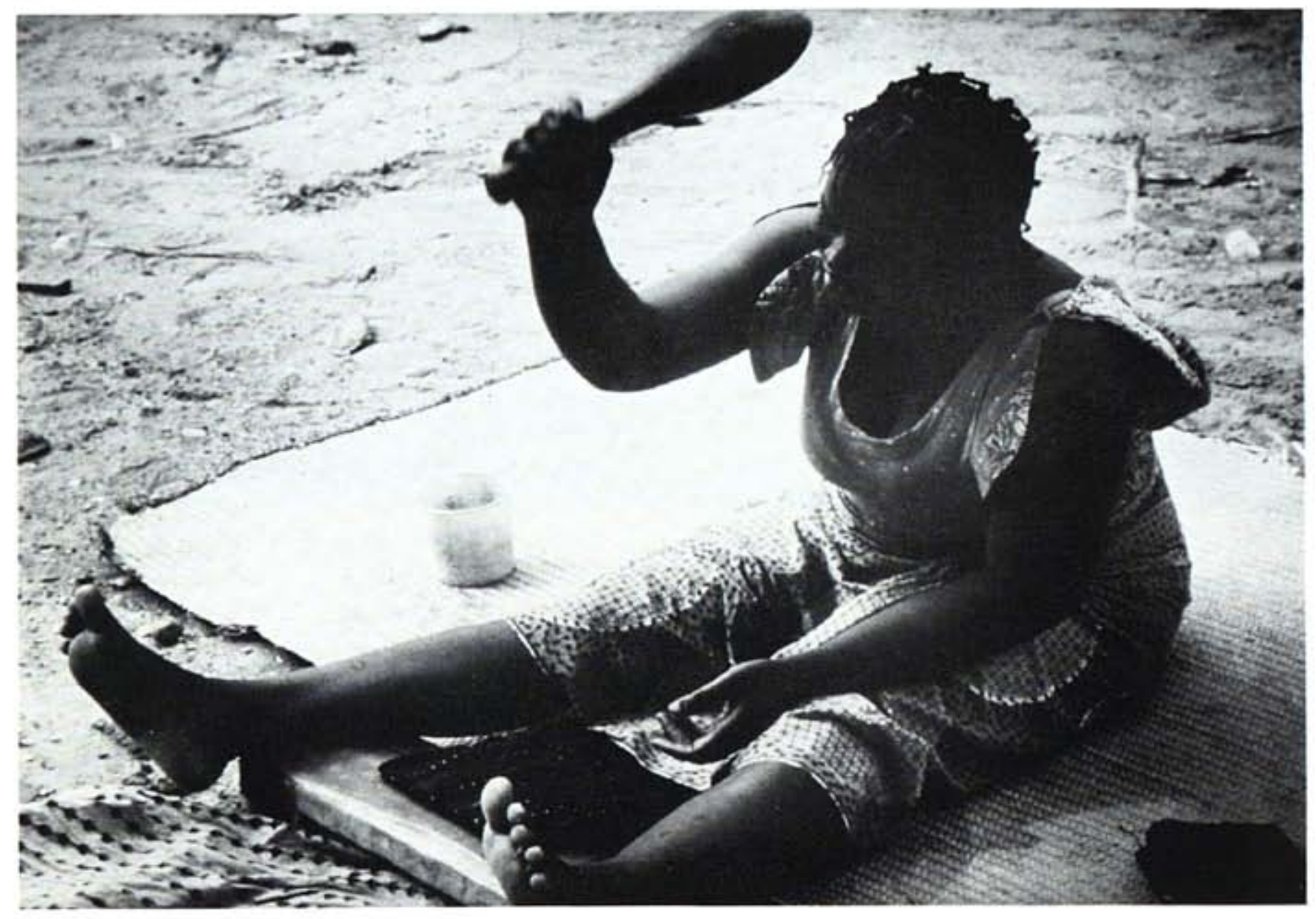


aries were paid regardless of income; all members received equal salaries despite widely varying production records; untrained members were elected to keep the cooperative's books. Yet these unorthodox rules represent rational responses to members' own evaluation of their overall social and economic situation. Donors and government agencies should make sure members understand the costs of such decisions and should seek compromises that maintain the women's own priorities while increasing profits.

\section{Appropriate technical assistance} is vital. Without outside advice the Markala group would not have achieved its goal of job training. One of the most improtant services that can be provided is to identify useful advisors and skills while allowing the cooperative to decide the direction of the project. In this case, officials of the ministry of Agriculture provided technical advice but also put the women in contact with donors that could help them.

4. A delicate balance must be main-
tained between self-reliance and ade-
quate levels of outside financial and tech-
nical assistance. The members were
anxious to maintain their independence;
they therefore avoided relying on any single
donor or government service. Their inde-
pendence has been expensive, since the
members have borne heavy costs for train-
ing and project development - costs which
might have been covered if the project had
been sponsored by an agency or a volun-
tary organization. The resultant lack of
capital has limited the cooperative's growth
and kept members' salaries low. On the

other hand, highly subsidized projects often fail once subsidies are withdrawn. The Markala group's stability seems assured since they have learned to function autonomously in the face of a wide range of problems and a sometimes adverse financial situation. Donors and beneficiaries must work together to structure financial assistance that encourages self-sufficiency without forcing poor women alone to bear the financial risks of experimental projects.

\section{Bookkeeping and management} are as important as production skills if a small business is to succeed. In their enthusiasm for training that would benefit all members, the women concentrated on soapmaking and cloth-dyeing skills. They neglected technical training for those members chosen to keep the books yet were unwilling to hire a trained outsider to serve as manager or bookkeeper. As a result, the lack of timely and good accounting information has limited the cooperative's profitability. When planning projects, the importance of such skills should be emphasized.

\section{A flexible, long-term perspective} is essential. It took several years for the members to develop their job skills, and even longer for the women to build confidence in one another. By starting simply and adding projects only as the members felt ready, the group stabilized and strengthened their project. Rigid project designs and unrealistic time frames should not be imposed; six years after the group was formed, the members of the Markala cooperative view their work as having just begun. 


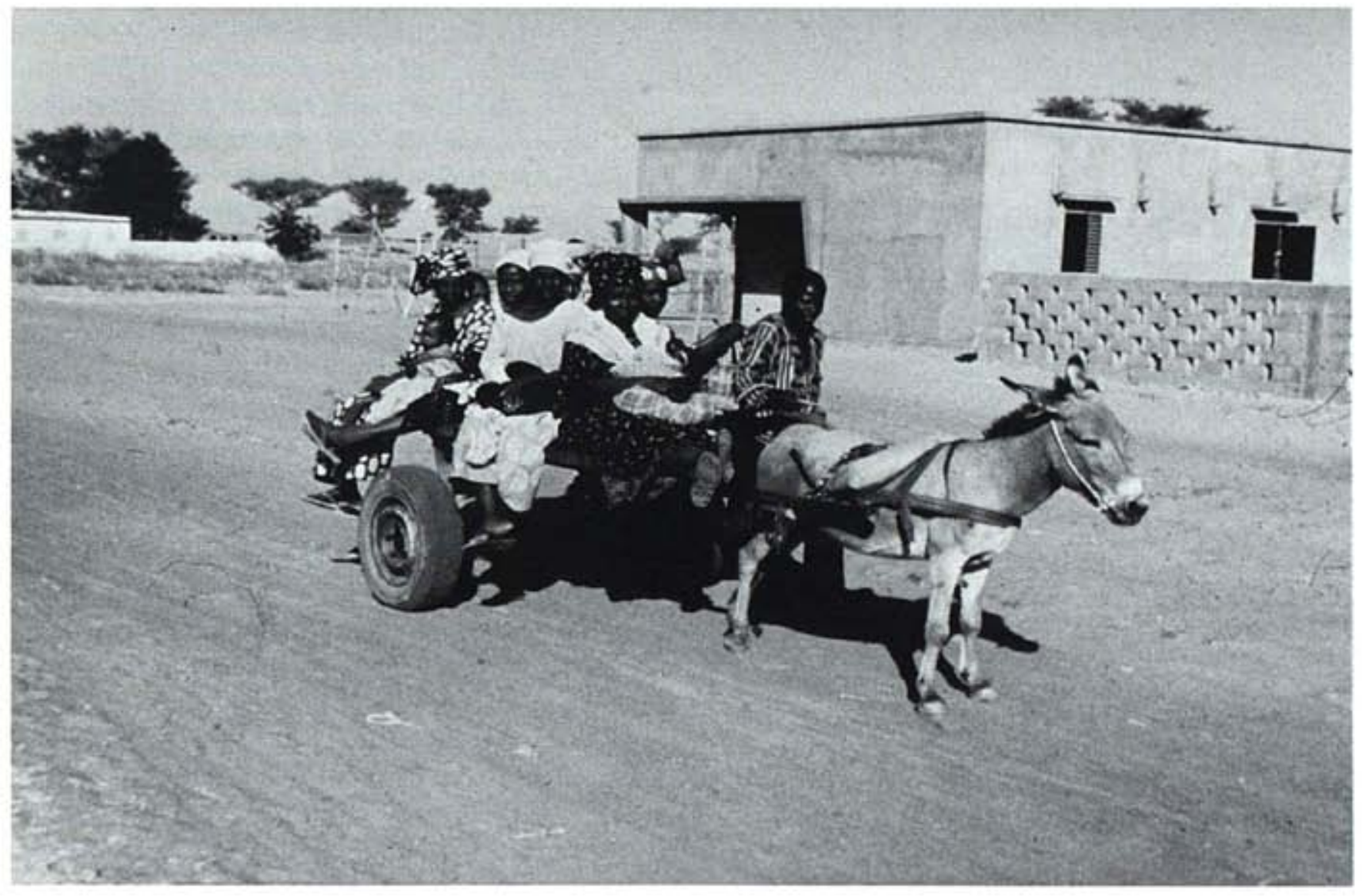




\section{Appendices}

\section{Rural Extension Services in Support of Women's Income-Generating Activities}

The Markala Cooperative's success has been primarily a product of the hard work and determination of the members. However it also has been helped to a great extent by the existence of rural outreach programs. As noted in the text, a local Ministry of Agriculture official brought the group to the attention of donor and government agencies. Then in 1976, the American Friends Service Committee (AFSC), in cooperation with the Ministry of Rural Develop- ment, established a women and development program (Femmes et Developpement or FEDEV in French) in Mali. This organization has been able to provide training for the women and an outlet for the sale of their cloth. Until this time, effective, governmentally supported, rural extension services to assist the efforts of women's groups had been rare.

The following description of FEDEV and two similar projects shows how such structures, established within government ministries, can play a vital role in helping rural women to develop skills and establish viable businesses.

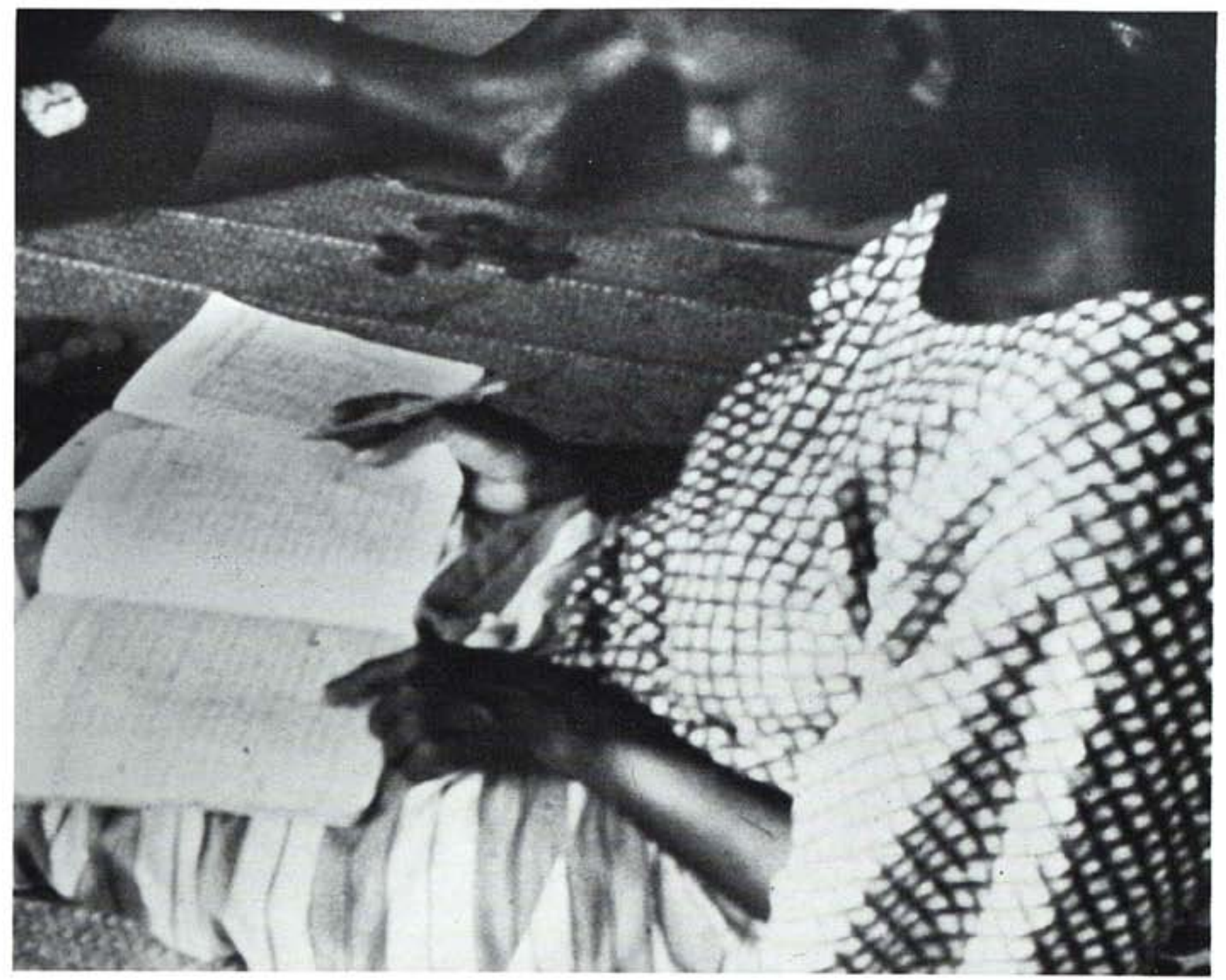




\section{Femmes et Development (FEDEV) Project Bamako, Mali}

The FEDEV project is quasi-governmental in character, reporting directly to both the Ministry of Rural Development and the AFSC. It also reports to the government office responsible for supervising the work of private voluntary organizations in Mali. The Director of the Division of Rural Animation and Training assists FEDEV by assigning staff (rural extension workers), informing local officials of FEDEV activities and integrating FEDEV programs with other government and private efforts.

Now active in five of Mali's seven regions, FEDEV works primarily through district level rural extension workers known as monitrices. These women are connected with rural multi-service centers where they work with village women on health and social needs. Currently there are ten monitrices assigned to work with FEDEV. FEDEV provides advice, training (e.g., training in tie-dyeing techniques, soap-making, bookkeeping and general cooperative management) and resources that allow them to expand their role in the community into the area of women's income-generating activities. They receive a bonus for their work with FEDEV which is in addition to their regular activities. FEDEV also has provided a number of small motor bikes to facilitate the monitrices travel in rural areas.

The FEDEV program operates as follows. When a monitrice has identified a group of women desiring to start an incomegenerating project, she assists them in finding suitable space for their enterprise and makes arrangements for them to receive training in needed skills (e.g., soap making. tie dyeing. gardening, rug making). FEDEV provides the training and assists the women in organizing themselves as a business (electing officers, selecting a bookkeeper, deciding on cost of shares, dividends, salaries, etc.) in what is called a "pre-cooperative" structure. Becoming a coopera- tive in Mali is a complicated legal process that generally is not undertaken until a group has demonstrated its ability to work together and its profitability.

Good accounting procedures are recognized as critical to the success of any business and FEDEV not only provides training in this area but occasionally pays a small stipend to the bookkeeper during the initial period of operation until the cost can be assumed by the group. When necessary FEDEV also provides start-up capital for tools and equipment and purchases some supplies in bulk which it distributes to the groups at cost. Assistance with marketing products produced by the groups also is provided.

Each monitrice stays in close contact with all pre-cooperatives in her area, sometimes visiting each one several times a month. Through its training and support services, FEDEV expects that over a period of a few years each group will be able to:

- achieve financial viability

- develop a sound organizational structure

- establish a marketing system for its products

At this point the groups should be able to qualify for legal recognition as cooperatives within Mali which will allow them to receive consultation and training from the Cooperative Section of the Ministry of Rural Development.

Government officials in Mali have shown increasing interest in FEDEV activities. They are invited to visit the groups to see for themselves what the women are doing. One visitor to Markala was quite surprised at the quality of soap being made by the cooperative. Such exposure helps planners appreciate the importance of women's economic roles and the costeffectiveness of rural extension services, thus justifying continuing governmental support.

Based on the success of the FEDEV project, the AFSC recently has initiated a similar project in Guinea-Bissau. 


\section{Women in Development Project Ntfonjeni, Swaziland}

This project, officially titled "Assistance in Strengthening Income-Generating Capabilities Among Rural Women and Their Families," was begun in 1975 as a pilot scheme to integrate women into the national development effort by assisting them in acquiring and improving income-generating skills in small-scale, rural home industries. Headquartered in Ntfonjeni, in northern Swaziland, the project thus far has trained 406 women through two, four-month training programs.

The Women and Development Project functions within the Department of Community Development and Social Welfare of the Ministry of Agriculture and Co-operatives. It also is linked to the Northern Rural Development Area Programme. It is fully institutionalized within the government structure.

Initial funding for the project came from the U.N. Department of Technical Cooperation for Development. The project now receives its principal funding from the Government of Swaziland's various bilateral and multilateral sources.

In addition to income-generating skills, the project provides day care centers, a village technology unit which demonstrates labor saving devices, a revolving loan fund to assist graduates of the training programs to buy equipment and raw materials and marketing assistance which includes an advisory service that offers counsel on design, equipment and production problems.

The project currently is expanding to three other areas in Swaziland and discussions are planned on the possibility of establishing similar projects in other countries.

\section{IRDP Pilot Project in Population Planning and Rural Women's Cooperatives Bangladesh}

The Integrated Rural Development Programme (IRDP), a major institution under the Ministry of Labour, Administration, Local Government and Rural Development and Cooperatives, was designed to organize farmers into village level cooperatives. Not surprisingly these cooperatives had only male members. So in 1974, the IRDP set up a women's program to organize women's village level cooperatives.

All rural women are eligible to join a cooperative in their village by purchasing a share in the cooperative and by agreeing to meet and deposit savings weekly. As of 1979 there were 656 women's cooperatives operating. Members then are entitled to receive credit for economic production in areas they consider appropriate such as raising livestock, processing rice, making pottery, tailoring, etc. Credit is extended to the cooperatives by banks and does not come from the women's savings. The members also are eligible to receive training. supplies and services to upgrade their projects. Elected cooperative officers receive special training in management and have access to information on various subjects, such as health and family planning, which they in turn share with the other members.

When the Programme began, there were no women officers on the IRDP staff. Female staff soon were recruited and now occupy line positions within the institution. All staff receive special training to prepare them to work effectively to meet the needs of rural women. 
Design: Sarah Vure

Typography: Village Type and Graphics

Photos: Susan Caughman

Printing: Graphic Impressions, Inc.

Susan Caughman was Director of the American Friends Service Committee's Women and Development Program in West Africa. Mariam N'diaye Thiam is responsible for women's programs in the Ministry of Agriculture, Mali. Together they founded the Mali Rural Women's Advisory Service, a program which now provides technical assitance to some $\mathbf{5 0 0}$ women in producer cooperatives in rural Mali.

We invite your comments and your ideas for projects which might be included in future editions of SEEDS. If you would like additional copies of this issue or would like to be included on the SEEDS mailing list, please write to:

Ann Leonard, Editor

SEEDS

P.O. Box 3923

Grand Central Station

New York, New York 10163 U.S.A. 


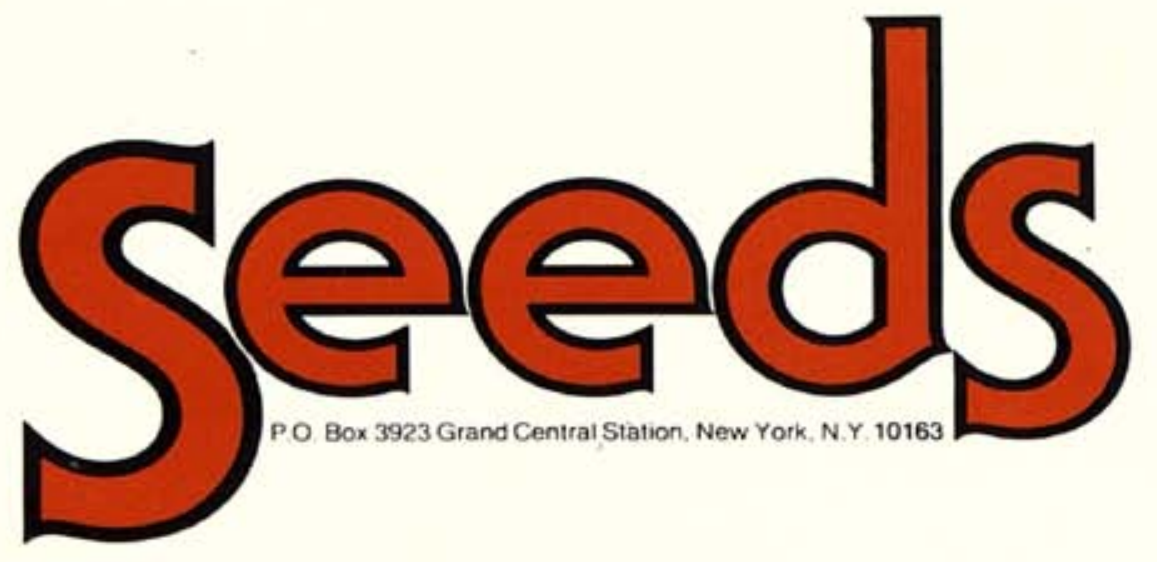

